Redakcja tomu Roman Mnich i Roman Bobryk. Siedlce: Uniwersytet Przyrodniczo-Humanistyczny w Siedlcach, 2015). Novaja rusistika, 2015, č. 2, s. 76-81.

POSPÍŠIL, I. (2016): Frank Voll'man i jego polemiki o panslavizme. In: CHYRA-ROLICZ, Z, ROKOSZ, T. (eds): Panslawizm wczoraj, dziś, jutro. Siedlce, s. 147-160. POVARIN, S. I. (2009): O teorii i praktike spora. Moskva.

STARYGINA, N. N (2003): Russkij polemičeskij roman 1860-1870-ch godov v situacii filosofsko-religioznoj polemiki. Moskva.

https://doi.org/10.5817/NR2018-2-8

\title{
Solženicyn komplexně: tvorba, Polsko a emigrace
}

DĄBROWSKA, M., GŁUSZKOWSKI, P. (eds): Aleksander Sotżenicyn i rosyjska emigracja. Warszawa-Toruń: Instytut Rusycystyki Uniwersytetu Warsawskiego, 2018. ISBN 978-83-64869-21-1.

Na rozdíl od 60.-90. let 20. století zájem o osobnost Alexandra Solženicyna pohasl. Alespoň pokud jde o zájem povrchový, k němuž radím politické konotace nositele Nobelovy ceny. Na druhé straně je tu tedy šance zabývat se tím, čím Solženicyn vlastně začal, byt by to byla jen obvyklá maska ruských literátů směřujících od literatury řadou přesahů $\mathrm{k}$ politice, filozofii, dokonce kosmologii: jeho téma bylo výsostně politické, ale současně se autor ukázal jako umělec, jenž suverénně zvládl nejen drobnější útvary povídky a novely, ale také rozlehlou plochu románu, včetně historicky artikulovaného: jejich publicistické podoby vtělil do traktátů 9o. let 20. století, když se vrátil do Ruska a cestoval po něm, většinou nepochopen nebo posuzován značně kriticky až negativisticky. Snad tedy nastala doba pojmout Solženicyna opět sine ira et studio s koncentrací na uměleckou podstatu jeho díla, byt i víme, že to nobelovský výbor zajímalo asi nejméně. Mezinárodní konference a publikační výstupy poslední doby o tom svědčí snad právě proto, že autorova módnost už pominula, a zůstalo tak jen to, co je skutečně hodnotné. Možná toho nebude tolik, jak se dříve myslelo, ale to, co zatím v našem povědomí zůstává, je významné a patrně i nedoceněné.

Na konci 8o. a na počátku 9o. let minulého století, kdy se Solženicyn začal vydávat v SSSR a zemích jeho tehdejších satelitů, se o něm v Bratislavě konala konference pod záštitou děkana Filozofické fakulty Univerzity Komenského, rusisty Ivana Slimáka (1931-1996), s nímž jsem předtím domlouval brněnskou účast - bylo to v roce 1990. Slimák tehdy doufal, že se jí zúčastní i sám Solženicyn, jehož pozval, ale to se nestalo. Možná to bylo i štěstí (i když pro Solženicyna - vzhledem $\mathrm{k}$ jeho velkoruství - byly asi pohyby v bývalých sovětských satelitech pod jeho rozlišovací schopnost), protože 
konference se stala do značné míry plochou, na níž se odehrávaly osobní souboje jednotlivých rusistů, kteří si vyčítali, jak se k Solženicynovu dílu chovali za tzv. československé normalizace (1969-1989), nemluvě o měnícím se sovětském kontextu za glasnosti a perestrojky. Ostrá polemika se týkala také koncepcí ruské sovětské literatury: tuto poněkud zatuchlou atmosféru brzy radikálně proměnil Vladimir Lakšin (1933-1993), někdejší redaktor časopisu Novyj mir, ${ }^{1}$ jenž sem vnesl koordináty spojené s delikátními aspekty Solženicynova charakteru a jeho tvorby v jejich kritické reflexi v SSSR i mezi emigrací liberální i konzervativní. ${ }^{2}$

Př́tomný svazek je rozdělen do pěti oddílů. První je tematický okruh Solženicyn o př́tomnosti a minulosti. $V$ čele stojí studie polského rusisty, zakladatele emigrantologie a nezapomenutelného předsedy Mezinárodního komitétu slavistů, který do jeho činnosti vnesl výrazné reformní prvky, jež však byly v pozdějším vývoji potlačeny, Lucjan Suchanek (Krakov) Alexander Solżenicyn $i d w a$ eksperymenty antropologiczne $i$ etniczne [DĄBROWSKA, GŁUSZKOWSKI 2018, 11-24]. Pojal Solženicynovo dílo jako realizační plochu dvou antropologických a etnických experimentů. Oba svádí $\mathrm{k}$ dvěma variantám, a to $\mathrm{k}$ západnímu materialistickému humanismu a k sovětskému modelu, které vydaly dva plody, a to homo occidentalis, a homo sovieticus, za kterým se však skrývá také homo russicus, $\mathrm{k}$ němuž se Solženicyn radí vrátit, nebơ oba konstrukty, jak západní, tak sovětský, pomíjejí etnický princip a mírí $\mathrm{k}$ utopii. Jedna varianta skončila nezdarem, druhá pokračuje v nových souřadnicích. Suchanek se tu opírá o koncepce sovětského emigré A. Zinovjeva, jemuž věnoval knihu a řadu studií a konferencí. ${ }^{3}$ Pravda je, že spojování sovětské ideologie se Západem není nic nového, nebot geneze sovětského režimu ze západního myšlení jeho modifikací je zjevná a byla také předmětem řady úvah. Návraty k etnickému principu, posilování báze, jež je pro Solženicyna přirozená, se projevuje v řadě jeho provokativních úvah, ale také v krásné literatuře, at již se týká minulosti nebo jeho prrítomnosti. Jinak, řečeno: Solženicyn je proti utopickým projektům, hlavně takovým, které demiurgicky pozměňují přirozený biologický a společenský pohyb, ale sám někdy takovým utopiím podléhá, jak ukazují jeho návraty k předrevolučním pokusům o reformy.

Ve studii jednoho z editorů př́tomného svazku Piotra Głuszkowského $C z y$ rewolucji można byto uniknać? Spór Alexandra Solżenicyna z historia [DĄBROWSKA, GŁUSZKOWSKI 2018, 25-34] se zkoumají Solženicynovy názory na nezbytí revoluce v Rusku: ten vyjadřoval mínění, že revoluce je v Rusku spíše zvnějšku implantovaný proces (na

1 Viz náš překlad úryvku [LAKŠIN 1991].

2 Viz naše studie, knížku a překlady věnované Solženicynovi: [POSPÍŠIL 1992a], [POSPÍŠIL 1992b], [LAKŠIN 1991], [POSPÍŠIL 1994], [POSPÍŠIL 1999].

3 Viz naši studii [POSPÍŠIL 200o] a recenzi [POSPÍŠIL 1993]. 
rozdíl od některých jiných emigrantů, kteří zdůrazňovali organičnost ideje ruského komunismu - vzpomeňme také na proslulou knihu N. Berdajeva). I když byl Solženicyn vícekrát kritizován západními historiky Ruska (napr.. neustále přeceňovaný a citovaný Richard Pipes) za to, že vlastně historikem není a že jeho báze je ryze literární, podle mého soudu nelze Solženicynovy názory zcela odmítat - $\mathrm{k}$ tomu se poněkud kloní i autor studie, jenž zdůrazňuje, že základním materiálem je tu cyklus Rudé kolo (Krasnoje koleso), jenž je málo znám i samotným Rusům - mnohem výrazněji než všechny další Solženicynovy texty včetně Souostroví GULAG. K tomu dodávám, že Solženicyn se takto jeví jako více nebo méně amatér: jako spisovatel není dost estetický, jako historik a politolog je př́liš emotivní, jako jazykovědec je voluntaristický, ale ve všech těchto oblastech - často na rozdíl od oficiálních odborníků - ukázal na nové úhly pohledu a došel k novému, sice provokativnímu, ale podstatnému poznání: to se stalo v př́padě jeho jazykových úvah a polemik i jeho jiných vizí, přičemž charakteristické je, že právě v tom je Solženicyn velmi ruský: místo fragmentárních oblastí poznání je tu celková, komplexní vize, globalizující pohled na člověka a svět přesahující horizont Ruska.

Oddíl Kontakty polskie uvádí Tadeusz Sucharski (Słupsk) statí o recepci Solženicyna v polském londýnském týdeníku Wiadomości v letech 1965-1976 [DĄBROWSKA, GŁUSZKOWSKI 2018, 35-54]. Problém je, že se zde v názorech polských emigré expertů na Rusko, mezi nimi Józefa Mackiewicze, Józefa Łobodowského, Adama Pragiera aj., sráželo hledisko polské samostatnosti a ruského nacionalismu, takže se analýza uměleckých děl ocitla - jako takřka vždy - stranou.

Zbigniew Kaźmierczyk (Gdaňsk) v článku o předpovědích emigrantského osudu Alexandra Solženicyna [DĄBROWSKA, GŁUSZKOWSKI 2018, 55-63] ukazuje na názorech Czesława Miłosze na jedné straně jeho dobrý odhad Solženicynovy izolace v emigraci, na druhé to, že zejména Souostroví GULAG způsobilo v komunistickém hnutí na Západě šok, který je oslabil, a tak naopak posílil Solženicynovu pozici v emigrantském prostředí.

Oddíl o tvorbě A. Solženicyna zahajuje stat autora této recenze o Solženicynově žánrovém hledání; poté následuje studie Svetlany Martjanovové (Vladimir) o ruské a světové klasice na stránkách románu Alexandra Solženicyna V kruhu prvním. Autorka demonstruje, kterak Solženicyn hledal a nacházel jiný model recepce ruské klasiky, ale i literatury 2o. století než tehdejší sovětská literární kritika - jde mimo jiné o Lva Tolstého, s nímž ho kritika spojuje nejčastěji, ale i o Fjodora Dostojevského, Vladimira Solovjova a plejádu ruských a západních filozofů. I jeho přečtení ruské klasiky bylo tedy - jako vše, co dělal - originální. Monika Sidor(ová) (Lublin) ve své stati ukazuje Solženicynovu úvahu o únorové revoluci jako publicistický doplněk románového cyklu Rudé kolo. Př́nosná je i stat’ Alexandra Medveděva (Ťumeň) o ideologii a bytí v Solženicynově novele Př́ípad na stanici Krečetovka; nachází zde 
řadu skrytých vrstev, aluzí a sémantických signálů; část těchto významů souvisí i s tradicí Lva Tolstého, Michaila Bulgakova a obecně s empatií křest̉anství, což mi místy připadá nadnesené $\mathrm{v}$ duchu interpretací Mistra a Markétky; dílu se přikládá př́liš mnoho významů, jež lze z textu jen stěží odvodit; spíše si je autoři domýšlejí. Recepční estetikou se zabývají Jelena Olesinová a Ol'ga Stukalovová (Moskva) ve stati o sociokulturním kontextu recepce Solženicynovy novely Matrjonina chalupa: důležitý je zejména generační průřez, jenž ukazuje, jak se ruský čtenář mnohdy radikálně mění, ale také to, že v něm něco podstatného zůstává i napříč generacemi. Jelena Borisovová-Jurkovskaja (Varšava) se zabývá Solženicynovou Modlitbou za Rusko (Molitva o Rossii) ve světle ruské literární tradice básnické modlitby, jak se tu objevuje od 18. století, a dokládá to, jak dodáváme, jak se v nejsvětštějším ruském století před rokem 1917 udržuje sakrální ráz ruského písemnictví. Martyna Kowalska (Krakov) prezentuje postavení ženy v Solženicynově díle jako nositelky životního břímě, jež kulminuje ve vztahu mužů a žen v Souostroví GULAG. K tomu poznamenávám, že žena je tu viděna nikoli jako pouhý doplněk muže nebo jen jako jeho pomocnice, jak by se mohlo zdát, ale jako podstatná, dokonce dominantní životní síla - zcela podle vzoru Tolstého a Dostojevského; tedy žena jako dárkyně života, životní energie a jako samo jádro života. Podnětné jsou prŕspěvky o Solženicynově jazyce, resp. postoji k jazyku; první z pera Victorie Zayanchkauskayte (Lyon), druhý Volodymyra Dubichinského (Lingvističeskoje nasledije A. I. Solženicyna) z Varšavy.

Poslední oddíl svazku Solženicyn a ti druzí (Solženicyn a okolí, Sołżenicyn i otoczenie) zahajuje Tatiana Victoroff (Štrasburg) pojednáním o jeho spolupráci s YMCA-Press a korespondenci s N. A. Struvem. Právě z dnešního hlediska vrcholně rezonuje stat Sergeje Zasorina o Solženicynovi a ukrajinské otázce: nebyl bych v názoru na tzv. Solženicynův nacionalismus v této věci tak striktní a nevěcný, i když i on připouští vnitřní složitost jeho postoje. Možná bychom nemuseli hledat ani tolik složitostí jako spíše celkové ukotvení jeho názoru, který především vyplývá z jeho hlubinného hledání společných kořenů. Pozoruhodné je také srovnání Alexandra Solženicyna a Varlama Šalamova z pera Bożeny Żejmo (Toruň), v němž jsou ukázána společná místa, ale také odlišné chápání člověka podle Dostojevského jako „př́liš širokého“, schopného měnit základní znaky morálky na zcela opačné. Podobně srovnávacím způsobem postupuje Monika Zielińska (Varšava), když ho srovnává $\mathrm{s} \mathrm{V}$. Vojnovičem a analyzuje jeho negativní postoje $\mathrm{k}$ němu prezentované $\mathrm{v}$ jeho dílech. Zdánlivou marginálií je práce Mariny Smoljaninové o rodině ruských enigrantů Krivošejinových, které Solženicyn zahrnuje do cyklu Rudé kolo (jsou zde také citovány různé epistulární dokumenty).

Svazek jako celek je obratně komponován, je, pokud jde o tematiku a názorová spektra, vyvážený: je zde hledisko společensko-politické, filozofické, komparatistické, biografické, žánrové, ale i emigrantologické, nebot tak se vlastně celý svazek jmenuje, 
i když fakticky pokrývá mnohem širší okruh problematiky. Polská rusistika se zde ukázala ve velmi dobrém světle: svými názory, koncepcemi, ale hlavně schopností soustředit kolem svých okruhů badatele z jiných zemí. A také to, že emigraci nelze brát jako jev výlučný, ale jako výslednici řady okolností, které se do ní promítají.

Ivo Pospišil

\section{Literatura:}

DĄBROWSKA, M., GŁUSZKOWSKI, P. (eds) (2018): Aleksander Solżenicyn i rosyjska emigracja. Warszawa-Toruń, 2018.

LAKŠIN, V. (1991): Solženicyn a ti druzí. Překlad I. Pospíšil. Demokrat, 6. 3. 1991.

POSPÍŠIL, I. (1992a): „Archipelag GULAG“ i russkaja tradicija „preodolenija literatury“. In: KOVAČIČOVÁ, O. (ed.): A. I. Solženicyn v kontexte európskej literatúry: sborník príspevkov zo sympózia o tvorbe A. I. Solženicyna, Bratislava 1992, s. 69-77.

POSPÍŠIL, I. (1992b): Od Bachtina k Solženicynovi. Srovnávací studie. Boskovice, 1992. POSPÍŠIL, I. (1993): Emigracja i tamizdat. Skice o wspólczesnej prozie rosyjskiej. Red. Lucjan Suchanek. Kraków 1993. SPFFBU, XLVI, D 44, 1997, s. 156-158.

POSPÍŠIL, I. (1994): Alexandr Solženicyn. Tematická jednotka pro střední školy. Brno, 1994.

POSPÍŠIL, I. (1999): Alexandr Solženicyn: Rusko v troskách (Ukázka ze stejnojmenné knihy, naklad. „Russkij put'“, Moskva 1998). HOST 15, 1999, č. 7, s. 42-47.

POSPÍŠIL, I. (200o): Poláci se dívají na Rusko (Lucjan Suchanek - Alexandr Zinovjev). HOST 16, 2000, č. 7, s. 44-46.

\section{Od metodiky výuky literatury k teorii, eseji a interview: invenční texty Iriny Kalusové}

КАЛУС, И.: Современная русская литература: статьи, эссе, интервью. Москва: Издательство «Согласие», 2017. ISBN 978-5-90670-977-6.

Šéfredaktorka moskevského internetového časopisu Parus [Russkij... 2018], odkud také pocházejí texty tohoto svazku, Irina Kalusová se provdala za Slováka Petra Kaluse, s nímž žije stř́idavě v Rusku (většinou) a na západním Slovensku; osobní prríčina 